\title{
THE REACTING TO THE PAST PEDAGOGY AND ENGAGING THE FIRST-YEAR STUDENT
}

\author{
Paula Kay Lazrus \\ St. John's University \\ Gretchen Kreabling McKay \\ McDaniel College
}

This chapter investigates the value of the Reacting to the Past pedagogy with regard to engaging first-year students. In recent years, calls to improve student engagement and active learning techniques have grown, and few have been as successful in producing the desired results as

\footnotetext{
We extend our thanks to Mark Carnes, Ann Whitney (Olin Professor of History at Barnard College), Dana Johnson, and the Reacting Advisory Board for the work they do for Reacting to the Past. We offer this chapter in support of professors using the pedagogy and to encourage faculty members who have not taught with Reacting to do so. Special thanks to Judith Shapiro, professor of anthropology and president Emerita of Barnard College, for helping us organize the panel (March 2009) at the Conference for Academic Renewal sponsored by the Association of American Colleges and Universities that led to this chapter. In addition, P. Lazrus thanks the Center for Teaching and Learning and the Writing across the Curriculum programs at St. John's for organizing helpful and successful faculty writing retreats.
} 
Reacting to the Past. This chapter investigates why Reacting is so successful in meeting the goals of high-impact practices that increase student engagement and learning. We also examine bow the Reacting pedagogy and first-year seminars encourage problem solving, critical thinking, and writing among students.

O

One of the most prominent concerns for institutions working to strengthen their general education curricula, and especially their firstyear programs, has been the drive to improve student engagement while also assessing student learning. Whether the focus is incorporating active learning techniques, improving critical thinking, or addressing ways to improve students' abilities to connect classroom learning to the real world, professors and administrators have been exploring all manner of high-impact methodologies that promote students' engagement in their education. But what do we mean when we use terms such as engagement, active learning, and critical thinking? In this chapter, we propose that engagement is best understood as an aspect of active learning. That is, engagement is not simply the involvement in school activities, an issue that was recently highlighted in the study and book Academically Adrift (Arum \& Roksa, 2011). Among the findings in Arum and Roksa's study is the administrative push for retention that often leads campuses to focus on student activities in residence halls, student organizations, and other cocurricular programming rather than the role academics might play in keeping students engaged. We argue in this chapter that the Reacting to the Past (Reacting) pedagogy engages students deeply in their classrooms, putting the focus of student engagement on learning, and can be particularly effective when paired with first-year seminars.

With all of the emphasis placed on engagement outside the classroom, many have wondered if it can happen in the academic classroom. We are convinced that it can, if students participate directly in the act of learning through research, writing, reasoning, oral presentation, and teamwork. The Reacting pedagogy gives students a chance to embrace all of these elements of active engagement, which are the foundations of learning in a liberal arts education and the skills that all citizens must have to be active members of their communities. Active learning of this type contrasts with the simple acquisition of content delivered to students by professors, or the passive response systems like clickers that are often promoted as active learning techniques. Active learning involves the acquisition of 
knowledge by the student while building skills that most employers require of their employees, and make for strong scholars and citizens.

For active engagement to work well, students and professors must agree to be partners in the learning process. Simplistic debate that reduces college learning to content versus skills overlooks the fact that if you cannot reason or question what you are reading or being taught, then all the memorization in the world will not make you more learned or productive (Berrett, 2011; Bok, 2006). Simulations and role playing have long been used in the classroom. The National Model UN programs have a forty-year record of teaching through hands-on learning, and business and management classes have adopted similar exercises. Role playing of this sort heightens the experiential nature of learning which studies have shown to be among the most effective ways of retaining information ("Welcome to National Model United Nations," n.d.; Gorton \& Havercroft, 2012; Lane, 1995).

Among the many excellent teaching methods and curricular programs developed in this context, the Reacting pedagogy is among the most innovative and creative. Both of us have used Reacting with our first-year students. Here we discuss why Reacting is so successful at meeting the goals set by the Association of American Colleges and Universities 2007 report on Liberal Education and America's Promise-LEAP (Kuh, 2008), the ideals of student engagement in academic pursuits, and the outcomes set by many first-year programs.

\section{The Reacting Pedagogy}

Reacting consists of elaborate, tightly structured role-playing activities that integrate high-impact teaching practices in a seamless manner that simultaneously allows students to explore pivotal moments in the human experience. According to Liberal Education and America's Promise (LEAP), high-impact practices such as First-Year Seminars, shared intellectual experiences, collaborative learning, intensive writing and research, and global learning (among others) have been repeatedly tested and proven to be beneficial to student learning (Association of American Colleges and Universities \& National Leadership Council, 2007). Combining the Reacting pedagogy with the first-year seminar (FYS) experience, which itself has been shown to be an effective practice for student engagement and learning, returns impressive results (Higbee, 2008; Lightcap, 2008). This is also noticeable when Reacting is used as part of core or general curriculum classes that are often required of 
first-year students in subjects ranging from theology and philosophy to history and science.

Developed in the late 1990s by Mark C. Carnes, professor of history at Barnard College, Reacting won the 2004 Theodore Hesburgh Award for innovative pedagogy (TIAA-CREFF Institute, n.d.; Carnes, 2004). Reacting consists of units referred to as "games." As increasing numbers of professors use the pedagogy, it continues to be strengthened and improved by those teaching with Reacting as well as by those writing new games, and all those who participate in the yearly Reacting Institute at Barnard. This results in a form of constant peer review and improvements to the pedagogy. Students purchase the gamebook as they would a text, and this contains background information, schedules, instructions, and primary documents. As each game unfolds, students are immersed for extended periods (typically nine to twelve twice-weekly classroom sessions) in the contextual world in which the topical events take place. In the initial, or setup, phase, which typically lasts three class sessions, the professor leads discussions and lectures on the background and context of the historical period in which the game is set. During this phase, students complete primary and secondary source reading and begin additional research as necessary. At the end of this phase, students are assigned roles or characters from within the historical context and a set of victory objectives to achieve before the game ends. In some cases, they begin working with other characters/students to develop partners and build coalitions to support their ongoing objectives.

The second phase of every Reacting game unfolds as the students begin to apply and use the knowledge they have learned in the setup phase by interacting with one another, debating intrinsic ideas and issues from the period, all while using primary texts and documents as evidence for their arguments. In addition, the students take on increasing responsibility for the organization of class time. It is this feature of the Reacting pedagogy that provides students the chance to apply the knowledge to real-world problems. The discussions and debates at the center of the Reacting pedagogy provide students with problem-solving challenges that require both individual and team efforts. Developing students' ability to apply knowledge to new situations is a learning goal for many higher education institutions, and Reacting offers a key exercise for students to develop and demonstrate those skills. Each student is challenged to work individually but also to come together with classmates to solve important issues at hand; for instance, in the Athens game, students consider whether Socrates should be put to death or exiled, and in the India game, students untangle issues surrounding that country's emergence from colonialism in 
a way that will satisfy the needs of its many diverse citizens. Like case studies used in law and business classes, students must respond to unexpected ideas, strategies and news supplied by their peers or by faculty members thus reinforcing their critical thinking capacities.

Faculty members are provided with separate detailed materials (available through a free online collaborative forum), developed with great care, that include all the roles, texts, and other contextual information they need to manage the game. Students are expected to do additional research so as to understand how their character would think and to flesh out the topics they will have to address, pushing them to take more initiative in their own learning. In the first-year seminar or other introductory general education classes, students may not be comfortable with the research process. Thus, professors often take some additional time to build in basic research and referencing instructions, which might include how to find appropriate texts and cite them.

Every Reacting game emphasizes oral communication. Students give speeches on their assigned or chosen topics and respond to questions from fellow students in the give-and-take of the discussions. All game activities require students to move beyond simply looking up information. Papers are written in the first person (from the point of view of their role) and must be consistent with their character's knowledge during the time frame of the game. Such a scenario pushes students to engage actively in their own learning in order to complete additional research to prepare for the questions posed by their classmates and helps them focus on applying the information gleaned from their reading to the actual issues being addressed in the class forum. Plagiarism is reduced because of the firstperson nature of the writing. Students are required to think critically about the problems and concerns they are addressing in a contextual manner and must analyze information rather than simply memorize it. Students must think on their feet when answering questions after giving their speeches. They use the information they have gathered in their formal speeches and papers, but also in response to unscripted, and perhaps unexpected, questions from their fellow students in opposing factions. Because there is both a written and oral component to class work, students begin to move from the notion of writing a paper for their teacher to conceiving of writing as a method of sharing and transmitting ideas.

But Reacting is not a scripted debate. In fact, although the games are carefully crafted to produce outcomes that are similar to those that occurred historically, they are not fixed, and thus it is possible for the class result to be ahistorical, which has been a concern of many faculty 
members. In defense of potentially anomalous outcomes, they provide excellent teaching opportunities for the final phase of the experience when the professor once again takes the reins of the class and explains not only what actually happened in the context explored (regardless of the actual class outcome), but clarifies specific events and instances that need more in-depth discussion. It also provides a moment to reflect on the contingencies of historical events and can be used to illustrate how many factors converge to produce any particular incident in history and its potential relevance to current events. Through Reacting, students learn that despite what may appear at a distance to be a predetermined outcome historical events are not, in fact, preordained.

Faculty who are reticent regarding the adoption of Reacting often express concern about carving out several weeks of class to investigate a particular topic in such detail, but there are always choices we make in class regarding what to cover. The interdisciplinary nature of the games and their intense skill building in areas important in the first-year curriculum usually convince even the most skeptical of faculty (Higbee, 2008). Reacting can be stressful for some students due to peer expectations of preparedness or because of the oral requirements, but no pedagogy serves all students. In traditional lectures there will be those who are bored, for example, or cannot keep up with the pace. It has been our experience and that of colleagues that a far greater percentage of students remain engaged in the class and turn in higher-level work than with a more traditional lecture format (Carnes, 2005; Higbee, 2008)

\section{Discussion}

In today's world, student interaction and cooperation can be difficult to cultivate. Since nearly all Reacting games include several different factions (or teams) that need to work together to achieve broad goals and persuade others to support their objectives and views, faculty can address this obstacle by offering students guidance in group work situations, including how to develop workload distribution, communication plans, and conflict resolution. Attempts to engage students directly in their own learning and to work with others is sometimes stymied by their immersion in the world of technology, which often cuts them off from one another despite claims to the contrary by online social networking sites. Reacting requires teamwork, and instructors may need to take time to explain the basics of working in groups.

The emphasis on factions results in multiple perspectives and encourages students in the development of persuasive arguments providing 
an excellent structure from which to learn positive ways of engaging with the material and each other. Reacting pushes students to teach one another and engage in informal forms of peer review while honing their critical thinking skills. All of this-the teamwork, persuasion, and critical thinking-requires students to be active participants in their own learning. The professor's role is to guide students to appropriate resources and provide coaching to fully understand the material, and regarding writing, reasoned argument and oral presentation skills. The students, however, take the lead and drive the activity. While professors are responsible for assessments (written comments and grading) on speeches and papers, the students lead the class as actors in this unscripted play. Some students may struggle with the relative freedom of choosing topics to speak or write about or having to make that decision on short notice in response to debates in the classroom. Although this format is challenging for some students, they benefit from learning how to make decisions, that what they have to say or write matters, and that they must be prepared and respect due dates.

The Reacting library of games offers a wide array of topics that are commonly found in core curricula and first-year seminars and extend beyond use in history classes. They range chronologically from the classical period to contemporary times, and in geographical extension from Puritan New England to Imperial China (Carnes \& Winship, 2005; Carnes \& Gardner, 2005). In terms of subject matter, they vary from examining the politics of nation building to the development of scientific advances and from Confucian ideals to the issues surrounding the call for the right of women to vote, whether in Athens or New York City, making them ideal for many liberal arts and sciences classes. Although they often have historical settings, they are by no means adopted primarily by history classes (Higbee, 2008). Reacting games use classical texts and materials on a globally diverse array of topics and thus provide a strong foundation for both teaching and learning in terms of interdisciplinarity and critical thinking.

Reacting can be offered in different ways. One method is to offer a stand-alone first-year seminar, which is usually composed of three different games or topics that can be linked by geography, chronology, or thematic focus. A number of institutions have chosen to use Reacting for first-year seminars including Trinity (Hartford, Connecticut), Smith, McDaniel, and Barnard Colleges. The combinations chosen will reflect the focus of the faculty member teaching the class, the size of the class, or the curricular focus in the course as defined more generally. The many choices available show the flexibility of Reacting, but the true importance 
of the pedagogy is the focus on critical thinking, reading, writing and speaking that any game brings to the classroom.

At McDaniel College, a four-year, private college in central Maryland, Reacting has been promoted by the school's Center for Faculty Excellence and has been used in connection with the first-year seminar program since 2006, when the Athens game was first used in a seminar on critical thinking. Reacting promotes critical thinking in several ways. Students must read primary texts to figure out why they hold the beliefs that they do and how to argue for their ideas persuasively. Because there are always characters in each game with strong beliefs on one or two ideas (and not all), there are moments when persuasive speaking will be successful. Critical evaluation of texts and ideas is promoted through the preparation of speeches on various topics that emerge in the game. Each student must write at least two papers that require in-depth research, but since they are writing in the first person and must use only materials that are time appropriate, it is possible for the professor to gauge just how well they have understood the fundamental nature of the argument they are making, and so will their classmates who need to respond to their ideas.

At McDaniel, McKay typically chooses three games for her first-year seminar. These games are chosen thematically. Usually the Athens game is paired with two games currently in development, Constantine and the Council of Nicaea: $325 \mathrm{CE}$ and The Second Crusade: The War Council of Acre, 1148 (Gaudette, in development; Henderson, in development). At St. John's University in Queens, New York, some individual faculty members have inserted a single Reacting game into the required first-year course entitled Discover New York. This course is designed to give students a foundation in the types of learning objectives outlined in the AACU's LEAP initiative such as critical thinking, research, writing, oral presentation. and information literacy, which are also the foundational curricular objectives of this class (Kuh, 2008). In Lazrus's classes, the game Patriots, Loyalists, and Revolution in New York City, 1775-1776 (Offutt, 2011) provides an opportunity to integrate the benefits of Reacting within the course's larger curricular objectives just outlined through her disciplinary perspective (archaeology, history, and anthropology). Having students read John Locke and Thomas Paine (among others) and use their ideas to guide the decisions New Yorkers made during the year leading up to the signing of the Declaration of Independence is challenging, but students learn to make reasoned arguments and support their ideas with textual and factual information, and that is the heart of critical thinking. 
McDaniel has created its own assessment of the pedagogy's effectiveness in the first-year seminar program through a survey that was distributed to students with Reacting as their first-year seminar. Approximately seventy students responded to this survey. The findings indicate that students engage deeply with texts and ideas in these Reacting first-year seminar classes. Students are asked what skills they have learned in the course and are not offered a list from which to choose; McDaniel wants them to assess their own learning. Sixty-one percent noted that they developed their abilities in public speaking and oral communication. In terms of student engagement, 91 percent of the respondents indicated that they would recommend Reacting to a fellow student. In McKay's most recent first-year seminar (2011), when polled for the required extra class hour, the students unanimously requested to meet in the library to research and prepare for the next day's speeches. This result indicates that students understand that to be engaged requires work-research, analysis, critical thinkingand that learning occurs through active research and the use of information. Similar surveys at Eastern Michigan University (where Reacting was inserted into a US History survey) also point to increased student engagement and learning. There, 82 percent of students across three sections reported learning more through the games and 78 percent said they had worked harder in the class than they would have otherwise (Higbee, 2008). They also reported staying after class more frequently to discuss topics and to have met more often with their professor (Higbee, 2008).

Reacting is now used by over 250 institutions of higher education in the United States and abroad (Powers, Burney, \& Carnes, 2009). The Reacting approach has been shown to promote the following learning outcomes, all of them LEAP objectives: inquiry and analysis; oral communication; critical thinking; integrative learning; and teamwork. In a survey conducted by the Reacting Advisory Board in 2009, faculty who had used Reacting in at least one class were asked to assess the pedagogy's potential to meet the student learning outcomes identified in the LEAP study. Specifically, faculty noted that Reacting to the Past was "very effective" or "effective" in producing student learning or skill development in the following areas: inquiry and analysis (96.2 percent), oral communication ( 96.1 percent), critical thinking ( 96.1 percent), integrative learning ( 92.4 percent), and teamwork ( 90.6 percent). Faculty also gave Reacting high marks in developing effective learning outcomes for written communication (86.75), knowledge of human cultures (88.7 percent), civic knowledge of democracy (86.5 percent), and ethical reasoning (75.5 percent) (Higbee, 2008; Stroessner, Beckerman, \& Whittaker, 2009). 


\section{Conclusion}

It is difficult to transmit the excitement and energy of participation or the depth of critical thinking and analytical skills that students develop without experiencing this method of teaching first hand. Students find the Reacting pedagogy empowering. While intellectually challenging, this method opens new avenues for students to safely explore different points of view (Stroessner et al., 2009). Sometimes the experience can be unnerving, but most students rise to the occasion and appreciate the opportunity to take control of their learning process. Shy students often blossom and occasionally become leaders; strong students learn new organizational and collaborative skills. Students who never knew they were leaders suddenly discover they have that capacity. The following quotations are but two examples of student comments that may illuminate the value of Reacting as a powerful teaching method from the student perspective: "Reacting was completely unique in my college experience. In playing those games, the words of Gandhi, Socrates, and other historical figures became mine, transcending the academic distance to which I had grown accustomed and tapping into a very personal, intimate realm. Their thoughts, their histories, their biographies are real and alive in my mind" (Houle, 2006). Another student said, "Before this game I would think of the Revolution the way that the textbook describes. I never thought of the people and what problems they faced, why they made certain decisions, how this all was affecting them, how they were living, or small details that occurred during that period of time. Throughout the game I began thinking of how much this truly affected the people of that time. They had to worry about their homes, themselves, their families, jobs, property, everything" (Voula Gavalas, St. John's University, class reflections, March 31, 2009). The changes that professors observe in their students after they have had a Reacting class have led many early adopters of the pedagogy to reach out to their colleagues and help them see how powerful a teaching and learning tool this can be. We both believe it provides a strong method for delivering content, as well as for engaging students directly in their own learning.

Faculty interested in adopting RTTP usually attend the annual Barnard Reacting Institute held in June in New York City or regional workshops as preparation. Centers for teaching and learning are also instrumental in this process: they often offer short workshops run by faculty who have used RTTP or sponsor faculty to go the larger events. RTTP has proven to be an effective way to integrate experiential learning and role playing into the curriculum and as a method of reinforcing critical thinking, 
group work, and oral presentation in the classroom. It can provide a model for addressing the challenges and opportunities inherent in such pedagogical strategies across other disciplines.

RTTP is a pedagogy that brings students face-to-face with a historical moment. Students are forced to engage in texts, debates, and issues from these times. The surveys and other assessments that have been done (Stroessner et al., 2009) testify to Reacting to the Past's power to engage students. Pairing Reacting with other high-impact practices, for instance, the first-year seminar, makes for an even more powerful experience. Reacting corresponds well with AACU's LEAP learning objectives and goals for students and is an example of a high-impact practice that we hope will be used at more institutions of higher learning in the future.

In terms of assessment, Reacting provides multiple opportunities to evaluate students' abilities and knowledge across diverse skill sets and the application of knowledge in problem solving, writing, and critical thinking. If professors also include a reflective component (written, online, portfolio, or in class), it can be used to gauge the depth and breadth of student learning not only in terms of content, but also in terms of their personal growth and understanding of the world in which they live. This is particularly true if reflective exercises ask students to use what they have learned to connect to current events. For instance, after discussing the merits of "just war" in the Second Crusade game, McKay asks her first-year students on the final exam to think about the wars in Iraq and Afghanistan through the lens of the ideas of "just war." Administrators who visit Reacting classes often are astonished by the level of interaction among students, the depth and intensity of discussion, and the overall engagement with the subject matter demonstrated by the students. This is truly active and engaged learning at its best.

\section{REFERENCES}

Arum, R., \& Roksa, J. (2011). Academically adrift: limited learning on college campuses. Chicago, IL: University of Chicago Press.

Association of American Colleges and Universities, \& National Leadership Council (US). (2007). College learning for the new global century: A report from the National Leadership Council for Liberal Education and America's Promise. Washington, DC: Association of American Colleges and Universities.

Berrett, D. (2011, September 25). Which core matters more? Differences in definitions of quality lead to new debates over the importance of teaching practical skills versus specific knowledge. Chronicle of Higher Education. 
Retrieved from http://chronicle.com/article/In-Improving-Higher-Education /129134/

Bok, D. C. (2006). Our underachieving colleges: $A$ candid look at how much students learn and why they should be learning more. Princeton, NJ: Princeton University Press.

Carnes, M. C. (2004). The liminal classroom. Chronicle of Higher Education, $51(7), B 7$.

Carnes, M. C. (2005). Inciting Speech. Change, 32(2), 6-11.

Carnes, M., \& Gardner, D. K. (2005). Confucianism and the succession crisis of the Wanli emperor (3rd ed.). New York, NY: Pearson Longman.

Carnes, M. C., \& Winship, M. P. (2005). The trial of Anne Hutchinson: Liberty, law, and intolerance in Puritan New England: Reacting to the Past. Upper Saddle River, NJ: Pearson.

Gaudette, H. (in development). The Second Crusade: The War Council of Acre, 1148. Retrieved from hrtp://reacting.barnard.edu/second-crusade-war -council-acre-1148

Gorton, W., \& Havercroft, J. (2012). Using historical simulations to teach political theory. Journal of Political Science Education, 8(1), 50-68. doi:10.1080/15512169.2012.641399

Henderson, D. (in development). Constantine and the Council of Nicaea: Defining orthodoxy and heresy in Christianity, 325 CE. Retrieved from http://reacting.barnard.edu/constantine-and-council-nicaea-defining-orthodoxy -and-heresy-christianity-325-ce

Higbee, M. D. (2008). How Reacting to the Past games "made me want to come to class and learn": An assessment of the Reacting Pedagogy at EMU, 2007-08. In J. L. Bernstein (Ed.), Making learning visible: The scholarship of teaching and learning at EMU. Ypsilanti: EMU. Retrieved from http:/l commons.emich.edu/sotl

Houle, A. (2006). Reacting to "Reacting." Change, 38(4), 52.

Kuh, G. (2008). High-impact educational practices: What they are, who has access to them, and why they matter. Washington DC: Association of American Colleges and Universities.

Lane, D. C. (1995). On a resurgence of management simulations and games. Journal of the Operational Research Society, 46(5), 604-625.

Lightcap, T. (2008). Reacting to the Past: Extended simulations and the learning experience in political science. Paper presented at the American Political Science Association Teaching and Learning Conference, San Jose, CA.

Offutt, W. (2011). Patriots, loyalists, and revolution in New York City, 17751776. Boston, MA: Longman. 
Powers, R. G., Burney, J. M., \& Carnes, M. C. (2009). Reacting to the Past: A new approach to student engagement and to enhancing general education (White Paper). New York, NY: Teagle Foundation.

Stroessner, S. J., Beckerman, L. S., \& Whittaker, A. (2009). All the world's a stage? Consequences of a role-playing pedagogy on psychological factors and writing and rhetorical skill in college undergraduates. Journal of Educational Psychology, 101, 605-620.

TIAA-CREFF Institute. (n.d.). TIAA-CREF Institute-TLAA-CREF Theodore M. Hesburgh Award Winner-2004. Retrieved from http://www.tiaa -crefinstitute.org/awards/hesburgh/2004/2004.html

Welcome to National Model United Nations. (n.d.). Retrieved from http://www .nmun.org/ncca.heml 